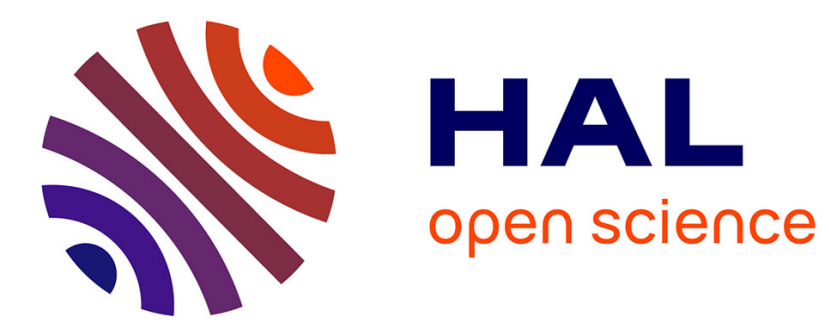

\title{
Imperfect transcript driven speech recognition
}

Benjamin Lecouteux, Georges Linares, Pascal Nocera, Jean-François Bonastre

\section{To cite this version:}

Benjamin Lecouteux, Georges Linares, Pascal Nocera, Jean-François Bonastre. Imperfect transcript driven speech recognition. Interspeech, 2006, Pittsburgh, United States. hal-02094739

\section{HAL Id: hal-02094739 \\ https://hal.science/hal-02094739}

Submitted on 9 Apr 2019

HAL is a multi-disciplinary open access archive for the deposit and dissemination of scientific research documents, whether they are published or not. The documents may come from teaching and research institutions in France or abroad, or from public or private research centers.
L'archive ouverte pluridisciplinaire HAL, est destinée au dépôt et à la diffusion de documents scientifiques de niveau recherche, publiés ou non, émanant des établissements d'enseignement et de recherche français ou étrangers, des laboratoires publics ou privés. 


\section{Imperfect transcript driven speech recognition}

Benjamin Lecouteux, Georges Linarès, Pascal Nocéra, Jean-François Bonastre

Université d'Avignon - \{benjamin.lecouteux, georges.linares, pascal.nocera, jean-francois.bonastre\}@univ-avignon.fr
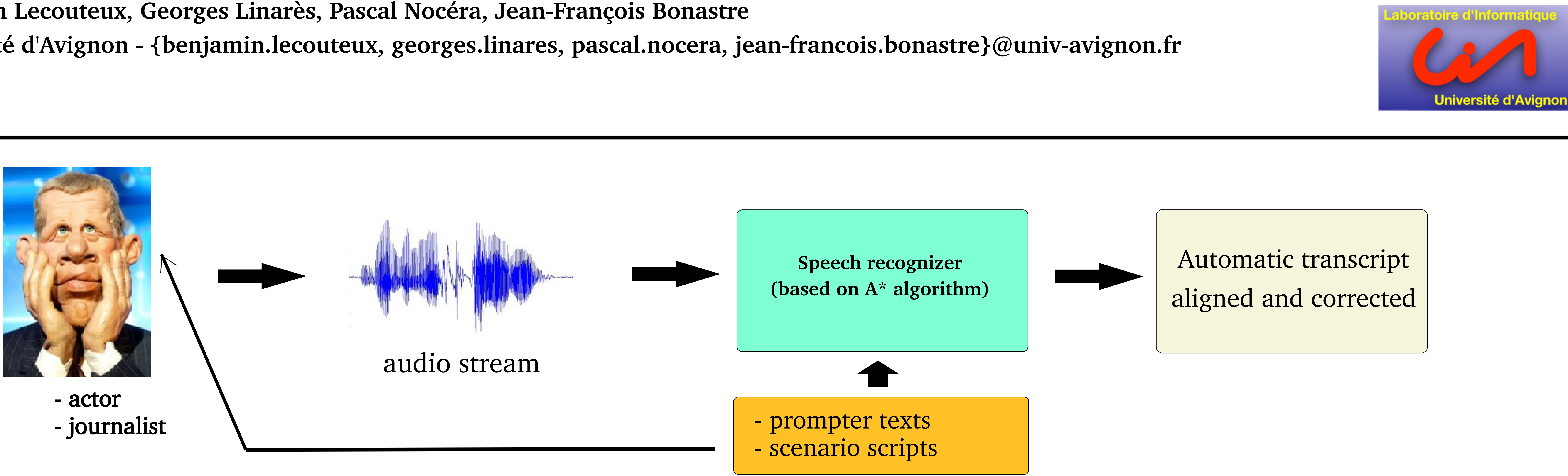

Automatic transcript

aligned and corrected

On-demand synchronization of the $A^{*}$ search with imperfect transcript by the DTW algorithm

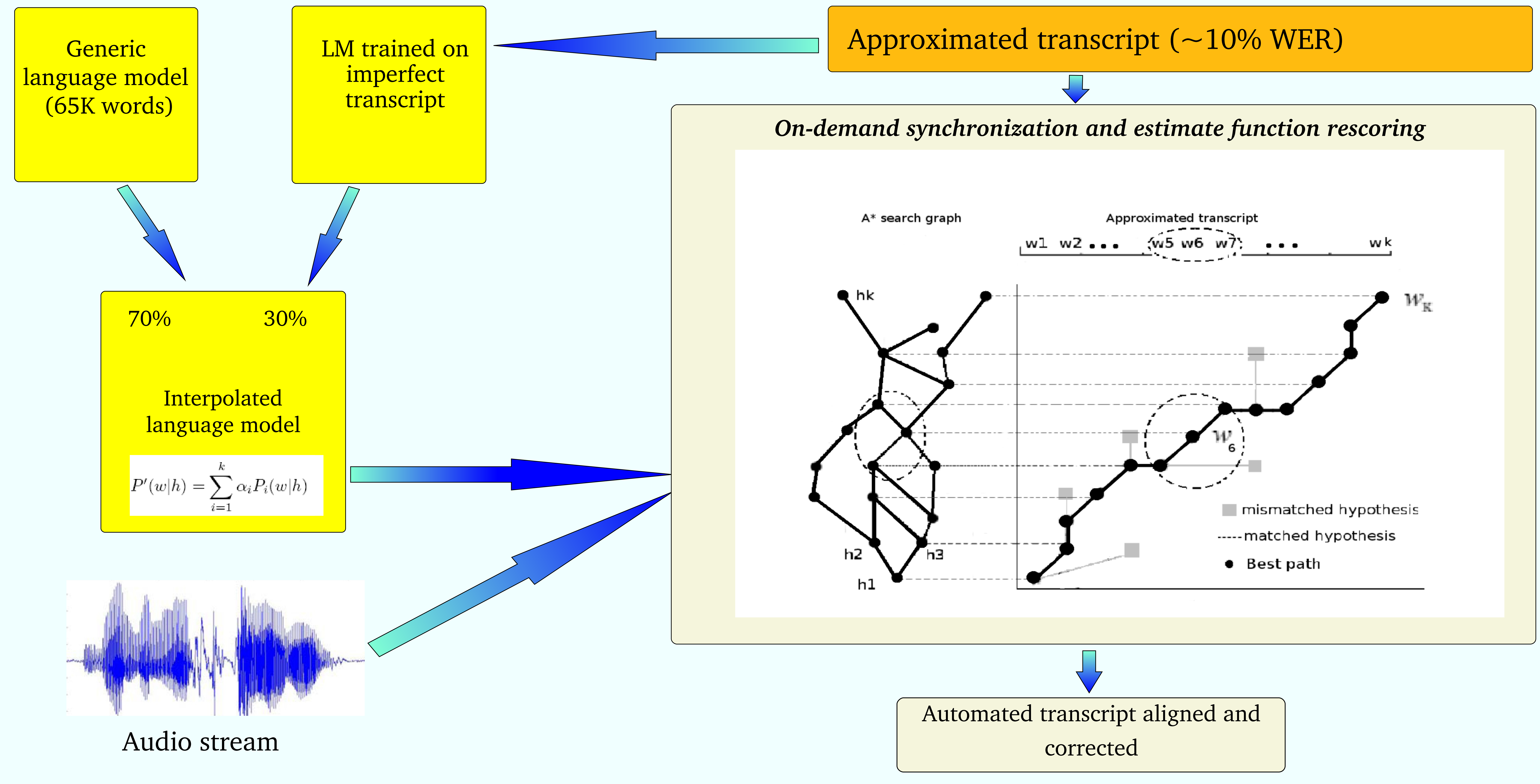

Alignment with $A^{*}$ algorithm during asynchronous decoding

- Each evaluated word is aligned to the reference word stream using a Dynamic Time Warping (DTW) algorithm.

- Once the hypothesis is synchronized with the transcript, the algorithm estimates the matching transcript-to-hypothesis score $\alpha$.

- Then, linguistic probabilities $P\left(w_{i} \mid w_{i-2}, w_{i-3}\right)$ are modified using the following rescoring rule:

$$
\tilde{P}\left(w_{i} \mid w_{i-2}, w_{i-3}\right)=P^{1-\alpha}\left(w_{i} \mid w_{i-2}, w_{i-3}\right)
$$

- $\alpha$ is maximum when the trigram is aligned and decreases according to the misalignments of the history.

\section{Alignment example.}

Prompter: france inter flash d'informations à huit heures un quart Pronounced text : france inter l' actualité à huit heures un quart

\section{Results after decoding:}

Without alignment : FACE À ELLE actualité à huit heures ET quart

With alignment: france inter l' actualité à huit heures un quart

\section{Experimental context:}

- Experiments assessed on 3 hours of radio broadcast - $10 \%$ WER introduced in transcripts

- Generic language model used : 65000 words trained on "Le Monde"

- Speech recognition system : SPEERAL, an asynchronous decoder based on the $A^{*}$ algorithm.

\section{Results :}

- Initial decoding : 22,7\% WER using a generic language model.

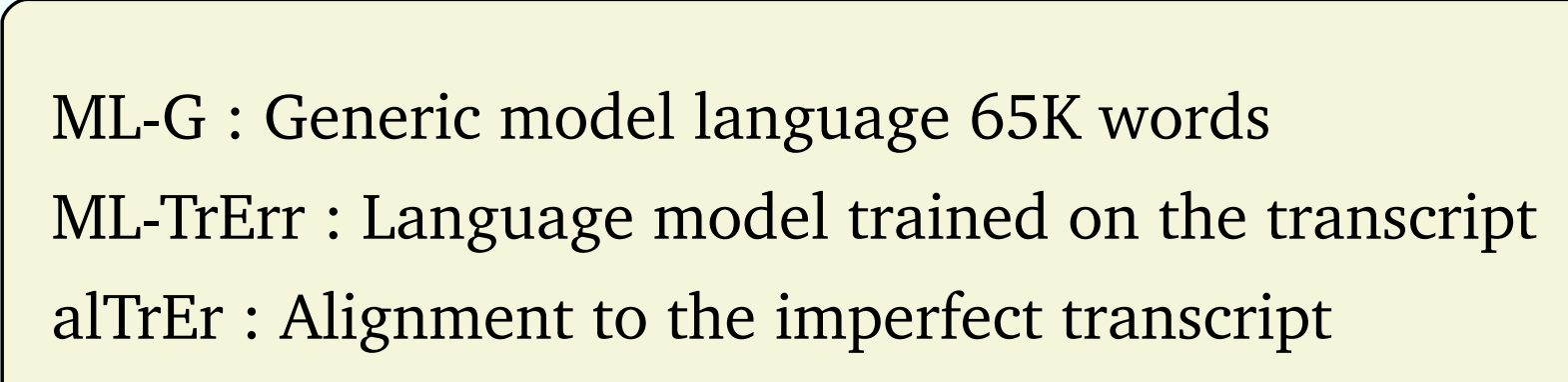

- Decoding using LM interpolation and alignment.

\begin{tabular}{|l|l|}
\hline \multicolumn{1}{|l|}{} & WË̈ \\
\hline ML-TrErr + aalignment TrEr & $9.9 \%$ \\
\hline ML-G + alignment TrEr & $7.7 \%$ \\
\hline ML-G70\%+ML-TrE30\%+alTrEr & $7.2 \%$ \\
\hline ML-G50\%+ML-TrE350\%+aITEr & $7.4 \%$ \\
\hline ML-G30\%+ML-TrEr70\%+alTrEr & $8.6 \%$ \\
\hline
\end{tabular}

- Decoding using language model interpolation.

\begin{tabular}{|l|l|}
\hline & Taux d'erreur \\
\hline ML-TrErr seul & $16.3 \%$ \\
\hline ML-G 70\% + ML-TrErr 30\% & $16.2 \%$ \\
\hline ML-G 50\% + ML-TrErr 50\% & $15.4 \%$ \\
\hline ML-G 30\% + ML-TrErr 70\% & $15.2 \%$ \\
\hline
\end{tabular}

\section{Conclusions :}

- Best results : interpolation $70-30 \%$ with forced alignment to transcript

- WER better than the transcript : $7.2 \%$

- relative improvement : $\mathbf{2 8 \%}$ 